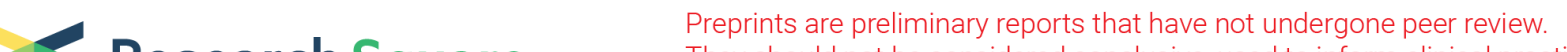 $\begin{array}{ll}\text { Research Square } & \text { They should not be considered conclusive, used to inform clinical practice, } \\ \text { or referenced by the media as validated information. }\end{array}$
}

\section{Pollutant Transport Via Sediments in Medium-Sized Meandering Rivers: The Example of Barium in Kupa River (Croatia)}

\section{Stanislav Franciskovic-Bilinski ( $\nabla$ francis@irb.hr)}

Institute "Rudjer Boskovic" https://orcid.org/0000-0002-3228-1244

Krešimir Maldini

Croatian Water Management: Hrvatske vode

Halka Bilinski

Institut Ruđer Bošković: Institut Ruder Boskovic

Tarzan Legović

Institut Ruđer Bošković: Institut Ruder Boskovic

\section{Research Article}

Keywords: Kupa River (Croatia), sediments, barium anomaly, sediment transport model

Posted Date: October 25th, 2021

DOI: https://doi.org/10.21203/rs.3.rs-989134/v1

License: @ (i) This work is licensed under a Creative Commons Attribution 4.0 International License.

Read Full License 


\section{Abstract}

The aim of our study is to expand the world-wide knowledge about pollutant transport in sediments of medium-sized meandering rivers and to explain barium distribution in Kupa River (Croatia), as it showed as an ideal "natural laboratory".

Sampling was performed twice at the same places with the time span of 15 years to see the changes in Ba concentrations after that period. Ba was analyzed using ICP-MS method on clay + silt sediment fraction $(<63 \mu \mathrm{m})$. Modelling was performed in $R$ environment ( $R$ version 3.5.1, 2018) and for solving the sediment transport equation of $\mathrm{Ba}$ in Kupa River a program based on finite differences is constructed.

After barite mine ceased operation in 1990, Ba is still entering Kupica and Kupa rivers, as karstic underground still contains large amounts of barite waste. Ba concentrations in Kupa River sediments are still increasing consequently along the whole river length, except in Kupica River and first downstream sample in Kupa River. It seems that in this part of river course erosion exceeded deposition processes. Also, there is an indication of changing the way of underground $\mathrm{Ba}$ transport. Erosion and deposition processes lead to formation of peak of Ba concentrations in the lower course of the Kupa River.

Most important conclusion is that the mentioned peak was formed under one or two flood episodes, when sediment eroded from the upstream locations and was brought and deposited in the lower course of the river. Our modelling predicts that Ba source will not cease completely during the next 20 years.

\section{Introduction}

A barium anomaly of a very high degree in sediments of Kupica and Kupa rivers was discovered in 2003 and results have been published afterwards (Frančišković-Bilinski 2005, 2006). Author of those studies found that Ba-contamination source originated from an abundant barite mine in Homer-Lokve area in Gorski Kotar region, Croatia. As a result of careless mine waste disposal in a channel leading to an abyss, the contamination penetrated through vulnerable karstic aquifers and appeared at Kupica River source. Biondić et al. (2006) performed a study in the Kupa River catchment. This study warned that the broader region of Kupa River basin, which is an area of deep karstic aquifers, is very vulnerable and that it should be protected as an important drinking water source.

Downstream Kupica River source the barium anomaly in sediments reached more than $120 \mathrm{~km}$ along both (Kupica and Kupa) rivers. During 1990 barite mine in Homer was closed. But, this didn't stop inflow of Ba into Kupica and Kupa Rivers, as karstic underground still contained barite rich mine waste, which is slowly washing out of cavities in karstic underground. This was also confirmed with our data. Our study has a potential to be used in the future to study sediment transport processes in rivers since they act as an excellent "natural laboratory". In spite that sediment transport research, particularly in rivers with gravel bed lasts for decades, it is still a difficult issue with a lot of unknown facts (Ancey et al. 2014). There are still plenty of open questions in this knowledge worldwide, also it is hard to find appropriate river to follow sediment transport processes. Therefore, we repeated sampling on the same locations in 
2018, exactly 15 years since the anomaly discovery, with the aim to see which processes happened during that time frame.

A fluvio-geomorphological study of the Kupa River drainage basin was performed by Frančišković-Bilinski et al. (2012). Besides fluvial geomorphology itself, this study investigated also ecological state of Kupa River. It was found that some parts of Kupa River, especially in its lower flow are in rather poor ecological state and under influx of pollutants. For example, during the summer months some stretches of Kupa River are getting locally moribund and arrested within its course. Severe eutrophication with macroalgal blooms and generation of marsh vegetation are present in some places. All those natural characteristics and anthropogenic interventions influence sediment transport in Kupa River and should be taken in account.

In the same quoted paper, Frančišković-Bilinski et al. (2012) calculated the sinuosity index for Kupa River, i.e thalweg length divided by the shortest distance from river source to mouth. It varies at different sectors of river with an overall sinuosity index of 2.20. Details and values of sinuosity index on some river stretches can be found in the quoted paper. According to its average sinuosity index, the Kupa River is classified into 'meandering' category of rivers (sinousity index=1.5- 4).

Frančišković-Bilinski et al. (2014) investigated magnetic susceptibility caused by presence of magnetic spherules in the upper flow of sinking Dobra River, an important tributary of the Kupa River. They followed distribution of magnetic particles until the abyss in which Upper Dobra River sinks and have found that those particles were retained in the karstic underground, as they were not found in lower flow of Dobra River and thus didn't reach its confluence with Kupa.

Interdisciplinary study of Förstner (2004) showed that most important dynamic features of sedimentrelated processes in rivers are dramatic effects of stormwater flood events on particle transport, intense effects of sulphide oxidation during resuspension and biological accumulation. Potential release of toxic chemicals is also significant. Fine-grained sediments and suspended matter are crucial for pollutant transport, due to their large surface areas and high sorption capacities. Authors concluded that different underlying processes should be studied in rivers prior to modelling the overall effects of pollutants.

Suitable rivers for investigating sediment and contaminant transport processes are rare in the world and therefore there are not so many such studies. And because of lack of such "natural laboratories", some scientists perform laboratory experiments to test their models.

One of such studies was study of Yilmaz (2008), who performed experimental study of sediment transport in meandering channels measured in a laboratory flume and those measurements were evaluated and compared with previous model studies. They found that the values of the calculated sediment transport rates are generally overestimated. They used the Einstein's approach (Einstein 1942) to measure experimental sediment transport rates and sediment transport capacities. They have chosen Einstein's approach for bed load comparison because it has been partially tested. 
Park and Ahn (2019) performed study of primary flow patterns and of mixing, using experimental (construction of meandering channel) and numerical investigations. Obtained experimental results were used to develop a model. Authors finally concluded that same types of velocity characteristics and pollutant transport could be defined with two-dimensional numerical models.

One of the rare studies performed on a real river was published by Nazir et al. (2016), who investigated sediment transport dynamic in a meandering fluvial system of Chini River, Malaysia, with the aim to study the riverbed erosion and sedimentation processes. It was found that Chini River has sinuosity index of 1.98, what confirms instability of this river and that intense erosion processes are present on some parts of this river. Continuous erosion process in waterways has increased the riverbank instability due to the meandering factors, what is similar to situation in our study area - the Kupa River.

Ciszewski and Grygar (2016) found that metal remobilization can be more intensive in alluvia than in soils. Such processes are result of erosion of river banks and of prolonged floodplain inundation. They are also associated with reducing conditions, which are alternating with oxygen-driven processes happening during dry periods.

Lauer and Parker (2008) performed a theoretical study on modeling framework, which was tested later on upper Clark Fork River, Montana, USA, which was exposed to mining activities. It was applied on sediment deposition, storage and evacuation in the floodplain of a meandering river and corresponding theory was developed.

The aim of the current work is to expand the world-wide knowledge about pollutant transport in sediments of medium-sized meandering rivers and to explain barium distribution in Kupa River (Croatia).

\section{Study Area And Sampling}

The Kupa River basin is presented in Figure 1. It is located in the western-central part of Croatia and its parts are also shared by two neighboring countries (Bosnia and Herzegovina and Slovenia). Kupa River is $294 \mathrm{~km}$ long. It is an important tributary of the Sava River, to which it inflows at Sisak (Croatia). The Sava River and its watershed occupy the south-western part of the Danube River watershed and inflows to the Danube River at Belgrade (Serbia). Kupa River and its whole watershed were intensively investigated during last two decades. Most important scientific studies performed were those of geochemical assessment of river sediments of the whole watershed (Frančišković-Bilinski 2007) and of fluvial geomorphology of the Kupa River (Frančišković-Bilinski et al. 2012). Most representative locations along both (Kupica and Kupa) rivers were selectd and sampling was performed there. Positions of those 18 sampling locations are presented in Figure 2 and details about sampling stations are given in Table 1. Locations IŠ and 51 are situated on Kupica River, while all other locations are situated along Kupa River. From locations on Kupa River location 52 is situated upstream Kupica River inflow, while other locations are situated downstream its inflow. For sampling were chosen those locations where fine grained sediment accumulates along the river bank. On each sampling site a composite sample of about $1.5 \mathrm{~kg}$ was taken. Such sample was taken from at least three grab samples of active fine-grained surface 
sediment $\left(0-5 \mathrm{~cm}\right.$ deep), collected on different places within a surface of $5 \mathrm{~m}^{2}$, what decreased the effects of local variability. The same sampling procedure was performed in 2003 and 2018 and sampling was conducted on the same sampling points, except two points: due to border problems with neighbouring Slovenia sampling point 50 at Žaga (left bank) from the year 2003 was moved in 2018 to nearest accessible site from Croatian side - Čedanj, located on the right bank $5 \mathrm{~km}$ upstream and was marked as ČD. As Ba-anomaly arrived from Kupica River, in 2018 one additional point not sampled in 2003 (IŠ) was sampled on Kupica River near Iševnica, 1.8 km upstream sample 51. 
Table 1

Details about sampling locations: locality, watercourse, to which watercourse it flows, geographical coordinates, elevation and sampling date

\begin{tabular}{|c|c|c|c|c|c|c|}
\hline $\begin{array}{l}\text { Sample } \\
\text { No. }\end{array}$ & Locality & Watercourse & $\begin{array}{l}\text { Flowing } \\
\text { into }\end{array}$ & Coordinates & $\begin{array}{l}\text { Elevation } \\
\text { (m.a.s.l.) }\end{array}$ & $\begin{array}{l}\text { Sampling } \\
\text { date }\end{array}$ \\
\hline \multirow[t]{2}{*}{2} & \multirow[t]{2}{*}{ Jurovo (beach) } & \multirow[t]{2}{*}{ Kupa } & \multirow[t]{2}{*}{ Sava } & $45^{\circ} 36^{\prime} 38^{\prime \prime} \mathrm{N}$ & \multirow[t]{2}{*}{135} & June 2003. \\
\hline & & & & $15^{\circ} 18^{\prime} 40^{\prime \prime} \mathrm{E}$ & & $\begin{array}{l}\text { and June } \\
2018 .\end{array}$ \\
\hline \multirow[t]{2}{*}{4} & \multirow{2}{*}{$\begin{array}{l}\text { Ozalj } \\
\text { (downstream HE } \\
\text { plant) }\end{array}$} & \multirow[t]{2}{*}{ Kupa } & \multirow[t]{2}{*}{ Sava } & $45^{\circ} 36^{\prime} 57^{\prime \prime} \mathrm{N}$ & \multirow[t]{2}{*}{122} & June 2003. \\
\hline & & & & $15^{\circ} 29^{\prime} 09^{\prime \prime} \mathrm{E}$ & & $\begin{array}{l}\text { and June } \\
2018 \text {. }\end{array}$ \\
\hline \multirow[t]{2}{*}{5} & \multirow[t]{2}{*}{ Jakovci Netretićki } & \multirow[t]{2}{*}{ Kupa } & \multirow[t]{2}{*}{ Sava } & $45^{\circ} 26^{\prime} 46^{\prime \prime} \mathrm{N}$ & \multirow[t]{2}{*}{198} & June 2003. \\
\hline & & & & $15^{\circ} 22^{\prime} 13^{\prime \prime} \mathrm{E}$ & & $\begin{array}{l}\text { and June } \\
2018 \text {. }\end{array}$ \\
\hline \multirow[t]{2}{*}{9} & \multirow{2}{*}{$\begin{array}{l}\text { Levkušje - } \\
\text { Zorkovac }\end{array}$} & \multirow[t]{2}{*}{ Kupa } & \multirow[t]{2}{*}{ Sava } & $45^{\circ} 35^{\prime} 54^{\prime \prime} \mathrm{N}$ & \multirow[t]{2}{*}{116} & June 2003. \\
\hline & & & & $15^{\circ} 31^{\prime} 40^{\prime \prime} \mathrm{E}$ & & $\begin{array}{l}\text { and June } \\
2018 \text {. }\end{array}$ \\
\hline \multirow[t]{2}{*}{$13 K$} & \multirow{2}{*}{$\begin{array}{l}\text { Karlovac - } \\
\text { Vodostaj }\end{array}$} & \multirow[t]{2}{*}{ Kupa } & \multirow[t]{2}{*}{ Sava } & $45^{\circ} 31^{\prime} 28^{\prime \prime} \mathrm{N}$ & \multirow[t]{2}{*}{111} & June 2003. \\
\hline & & & & $15^{\circ} 33^{\prime} 57^{\prime \prime} \mathrm{E}$ & & $\begin{array}{l}\text { and June } \\
2018 .\end{array}$ \\
\hline \multirow[t]{2}{*}{28} & \multirow[t]{2}{*}{ Donja Rečica } & \multirow[t]{2}{*}{ Kupa } & \multirow[t]{2}{*}{ Sava } & $45^{\circ} 28^{\prime} 51^{\prime \prime} \mathrm{N}$ & \multirow[t]{2}{*}{122} & July 2003. \\
\hline & & & & $15^{\circ} 39^{\prime} 60^{\prime \prime} \mathrm{E}$ & & $\begin{array}{l}\text { and June } \\
2018 \text {. }\end{array}$ \\
\hline \multirow[t]{2}{*}{29} & Zamršlje - & \multirow[t]{2}{*}{ Kupa } & \multirow[t]{2}{*}{ Sava } & $45^{\circ} 30^{\prime} 24^{\prime \prime} \mathrm{N}$ & \multirow[t]{2}{*}{121} & July 2003. \\
\hline & Gorenjski Kraj & & & $15^{\circ} 41^{\prime} 42^{\prime \prime} \mathrm{E}$ & & $\begin{array}{l}\text { and June } \\
2018 .\end{array}$ \\
\hline \multirow[t]{2}{*}{36} & Lijevo Sredičko & Kupa & Sava & $45^{\circ} 31^{\prime} 49^{\prime \prime} \mathrm{N}$ & 100 & July 2003. \\
\hline & & & & $15^{\circ} 53^{\prime} 04^{\prime \prime} \mathrm{E}$ & & $\begin{array}{l}\text { and June } \\
2018 .\end{array}$ \\
\hline 38 & Pokupsko & Kupa & Sava & $45^{\circ} 29^{\prime} 16^{\prime \prime} \mathrm{N}$ & 90 & July 2003. \\
\hline & & & & $16^{\circ} 00^{\prime} 35^{\prime \prime} \mathrm{E}$ & & $\begin{array}{l}\text { and June } \\
2018 .\end{array}$ \\
\hline 41 & Petrinja & Kupa & Sava & $45^{\circ} 26^{\prime} 41^{\prime \prime} \mathrm{N}$ & 91 & July 2003. \\
\hline & (beach) & & & $16^{\circ} 16^{\prime} 10^{\prime \prime} \mathrm{E}$ & & $\begin{array}{l}\text { and June } \\
2018 \text {. }\end{array}$ \\
\hline
\end{tabular}




\begin{tabular}{|c|c|c|c|c|c|c|}
\hline $\begin{array}{l}\text { Sample } \\
\text { No. }\end{array}$ & Locality & Watercourse & $\begin{array}{l}\text { Flowing } \\
\text { into }\end{array}$ & Coordinates & $\begin{array}{l}\text { Elevation } \\
\text { (m.a.s.l.) }\end{array}$ & $\begin{array}{l}\text { Sampling } \\
\text { date }\end{array}$ \\
\hline \multirow[t]{2}{*}{44} & Sisak & Kupa & Sava & $45^{\circ} 28^{\prime} 33^{\prime \prime} \mathrm{N}$ & 108 & July 2003. \\
\hline & (Zibel beach) & & & $16^{\circ} 21^{\prime} 35^{\prime \prime} \mathrm{E}$ & & $\begin{array}{l}\text { and June } \\
2018 .\end{array}$ \\
\hline \multirow[t]{2}{*}{45} & Letovanić & Kupa & Sava & $45^{\circ} 30^{\prime} 15^{\prime \prime} \mathrm{N}$ & 108 & July 2003. \\
\hline & & & & $16^{\circ} 12^{\prime} 03^{\prime \prime} \mathrm{E}$ & & $\begin{array}{l}\text { and June } \\
2018 .\end{array}$ \\
\hline \multirow[t]{2}{*}{49} & Severin na Kupi & Kupa & Sava & $45^{\circ} 25^{\prime} 30^{\prime \prime} \mathrm{N}$ & 158 & July 2003. \\
\hline & & & & $15^{\circ} 09^{\prime} 27^{\prime \prime} \mathrm{E}$ & & $\begin{array}{l}\text { and June } \\
2018 .\end{array}$ \\
\hline \multirow[t]{2}{*}{50} & Žaga (Slovenia) & Kupa & Sava & $45^{\circ} 31^{\prime} 41^{\prime \prime} \mathrm{N}$ & 223 & Only \\
\hline & & & & $14^{\circ} 55^{\prime} 24^{\prime \prime} \mathrm{E}$ & & 10.07.2003. \\
\hline \multirow[t]{2}{*}{51} & Brod na Kupi & Kupica & Kupa & $45^{\circ} 27^{\prime} 49^{\prime \prime} \mathrm{N}$ & 249 & July 2003. \\
\hline & & & & $14^{\circ} 51^{\prime 2} 22^{\prime \prime} \mathrm{E}$ & & $\begin{array}{l}\text { and June } \\
2018 .\end{array}$ \\
\hline \multirow[t]{2}{*}{52} & Brod na Kupi & Kupa & Sava & $45^{\circ} 27^{\prime} 53^{\prime \prime} \mathrm{N}$ & 246 & July 2003. \\
\hline & & & & $14^{\circ} 51^{\prime} 22^{\prime \prime} \mathrm{E}$ & & $\begin{array}{l}\text { and June } \\
2018 .\end{array}$ \\
\hline \multirow[t]{2}{*}{ ČD } & Čedanj & Kupa & Sava & $45^{\circ} 28^{\prime} 39^{\prime \prime} \mathrm{N}$ & 232 & Only \\
\hline & & & & $14^{\circ} 54^{\prime} 32^{\prime \prime} \mathrm{E}$ & & June 2018. \\
\hline \multirow[t]{2}{*}{ IŠ } & Iševnica & Kupica & Kupa & $45^{\circ} 27^{\prime} 02^{\prime \prime} \mathrm{N}$ & 255 & Only \\
\hline & & & & $14^{\circ} 51^{\prime} 05^{\prime \prime} \mathrm{E}$ & & June 2018. \\
\hline
\end{tabular}

\section{Materials And Methods}

\section{Sample preparation}

After sampling the sediments were dried in air at room temperature and then sieved through a $63 \mu \mathrm{m}$ sieve (Fritsch, Germany) to obtain fine fraction containing clay and silt $(<63 \mu \mathrm{m})$, on which study was performed. Approximately $0.1 \mathrm{~g}$ of representative powdered sediment samples was dissolved with $2.5 \mathrm{ml}$ of suprapur nitric acid and $7.5 \mathrm{ml}$ of puriss hydrochloric acid for half an hour at $1000 \mathrm{~W}$ in Anton Paar Multiwave 3000 Oven according to ISO 11466 norm and later diluted to $50 \mathrm{ml}$ with deionised water.

\section{ICP-MS analysis of elements in sediments}


The elements contents were detected by inductively coupled plasma-mass spectrometry (Agilent 8900 ICP-MS Triple Quad), with solution of $30 \mathrm{\mu g} \mathrm{L}^{-1} \mathrm{Ge}, \mathrm{Tb}$, In and Re as internal standard according to HRN EN ISO 17294-1 and HRN EN ISO 17294-2 norms. All measurements were performed in five replicas. The precision, evaluated directly as the relative standard deviation (RSD), was better than $10 \%$ for all determined elements. The accuracy of the ICP-MS analytical procedure and method quality control was performed by the analysis of the elements of interest in standard reference material (RTC, Trace elements on fresh water sediment, catalog number: CNS392-050), which were analyzed at the beginning and after analyzing each series of samples. A generally good agreement within $15 \%$ was observed between our data and the certified values.

\section{Mathematical modelling}

Law discovery of decrease in elevation above the sea level versus distance from the spring of the river Kupa, curve fitting and a transport law using modelling were performed in $\mathrm{R}$ environment ( $\mathrm{R}$ version 3.5.1, 2018). For solving the sediment transport equation of $\mathrm{Ba}$ in Kupa River and comparison to measured values in $2003 \mathrm{y}$, a program based on finite differences is constructed.

The same program was used to predict Ba concentration in sediments $130 \mathrm{~km}$ downstream Kupa during $2018 \mathrm{y}$. Finally, the program was amended to reconstruct the concentration past $130 \mathrm{~km}$.

\section{Results And Discussion}

\section{River elevation versus distance}

Longitudinal water elevation profile above the sea level of Kupa River from its source until inflow to Sava River is presented in Figure 3. This is an important feature for contaminant transport modelling in sediments. As one can see, a steeper slope prevails up to approximately $130 \mathrm{~km}$ downstream from the river source, the distance is found downstream the Ozalj hydropowerplant. Roughly, this point is approximately at the half of the total length of the river. From its source until its inflow to Sava River at Sisak, the height of Kupa River decreased for 217 m (from 313 m to 96 m) above the sea level.

\section{Sinuosity index}

Sinuosity index was calculated and discussed in details in the earlier research by Frančišković-Bilinski et al. (2012). This index is thalweg length divided by the shortest distance from river source to its mouth, but it can also be calculated for particular sections of a river. According to results from the mentioned paper, sinuosity index for the whole length of the Kupa River is 2.20 . When it is divided into sections, in the uppermost part of the river (from source to Žaga) it is 1.96. In the middle part of the river index is 2.42, while in the downstream part of the river from Karlovac to the confluence with Sava at Sisak it is 2.10. The value of sinuosity index mathematically describes the type of the stream. With its average sinuosity index of 2.20, the Kupa River belongs to the category of "meandering rivers", which have sinuosity index between 1.5 and 4.0 . 


\section{Barium concentrations in the Kupa River sediments in 2003 and 2018}

In Table 2 are presented all available data of Ba concentrations in sediments of Kupa River listed downstream the Kupa River from its source under Risnjak Mountain in Gorski Kotar until its inflow to Sava River at the town of Sisak. For each point the exact distance from the river source in $\mathrm{km}$ is given. 
Table 2

Barium concentrations in sediments of Kupa River listed downstream the river for both years (2003 and 2018). The distance from the Kupa River source is given for each sampling point.

\begin{tabular}{|c|c|c|c|c|}
\hline \multicolumn{5}{|c|}{ Kupa River } \\
\hline & $\begin{array}{l}\mathrm{km} \text { from } \\
\text { source }\end{array}$ & $\begin{array}{l}\text { Ba (ppm) } \\
2003^{*}\end{array}$ & $\begin{array}{l}\text { Ba (ppm) } \\
2018\end{array}$ & Comment \\
\hline & 0 & n.a. & n.a. & Kupa River source \\
\hline & 4,5 & 98.2 & n.a. & Upstream Ba inflow \\
\hline & 5 & 106 & n.a. & Upstream Ba inflow \\
\hline 52 & 23 & 75.2 & 317 & $\begin{array}{l}\text { Kupa about } 200 \text { m upstream Ba } \\
\text { source }\end{array}$ \\
\hline & 23.2 & n.a. & n.a. & Kupica inflow to Kupa: Ba- source \\
\hline ČD & 29 & n.a. & 782 & $\begin{array}{l}\text { Čedanj, closest sample to unavailable } \\
\text { K-50 }\end{array}$ \\
\hline 50 & 34 & 1070 & n.a. & Not available In 2018 \\
\hline 49 & 59 & 1060 & 1180 & \\
\hline 5 & 84 & 548 & 718 & \\
\hline 2 & 104.8 & 386 & 812 & \\
\hline 4 & 127 & 341 & 466 & \\
\hline 9 & 139 & 468 & 489 & \\
\hline $13 \mathrm{~K}$ & 155 & 262 & 233 & \\
\hline 28 & 164 & 199 & 357 & \\
\hline 29 & 174 & 74,5 & 212 & \\
\hline 36 & 197.5 & 122 & 332 & \\
\hline 38 & 213 & 78,4 & 373 & \\
\hline 45 & 244 & 99,2 & 343 & \\
\hline 41 & 262 & 54,4 & 256 & \\
\hline 44 & 278 & 65 & 185 & $\begin{array}{l}\text { Sisak Zibel - last sampling point in } \\
\text { Kupa }\end{array}$ \\
\hline
\end{tabular}

* Data for the year 2003 are taken from previous study of Frančišković-Bilinski (2006), while data for the year 2018 are original data obtained for the current paper.

n.a. $=$ not available 


\section{Kupa River}
286
n.a.
n.a.
Kupa inflow to Sava river

* Data for the year 2003 are taken from previous study of Frančišković-Bilinski (2006), while data for the year 2018 are original data obtained for the current paper.

\section{n.a. $=$ not available}

In Figure 4 are presented Ba concentrations in sediments (expressed in ppm) vs. distance from the source measured in the both studied years. As it could be seen from the figure, during those 15 years Baconcentrations increased significantly in the lowest course of the Kupa River and reached until its confluence with Sava River. Contrary to that, in the year 2003 in sediments of the last $100 \mathrm{~km}$ of the river course Ba-concentrations in sediments were not visible and they were approximately at characteristic background level for $\mathrm{Ba}$ in the studied region (<100 ppm).

\section{Ba-concentration ratios for years 2018 vs. 2003}

In Table 3 data are presented for all measured concentrations of $\mathrm{Ba}$ in sediments, including those from Kupica River (IŠ and 51), which is the source of Ba-contamination of Kupa River. Calculated ratios of Baconcentrations in sediments for years 2018 vs. 2003 are also presented in the table, as they are illustrating how many times Ba-concentrations on some point increased or decreased. One could notice that Ba-concentration on sampling location 51 (Kupica River just before its confluence with Kupa) decreased almost 5 times during this 15-year period, so contamination input decreased a lot during that period. This is due to the fact that since 1990 there is no new active Ba-input into the karstic background, as Ba-mine in Homer ceased operation. Obviously, a process of rinsing of karstic underground which was enriched with Ba-ore waste continued but less and less $\mathrm{Ba}$ is reaching Kupica source. Consequently, Baconcentrations in Kupica River started to decrease and therefore total input of Ba-contamination from Kupica to Kupa River dropped significantly. The same process is observed on the first downstream sampling location on Kupa River (50 and substitute location ČD). The most significant increase of Baconcentrations in sediments in the observed period of 15 years happened in the lower flow of Kupa River. On that stretch of the river in 2003 increased Ba-concentrations were not observed and they were approximately at the background level characteristic for this region $(<100 \mathrm{ppm})$ while 15 years later Baanomaly reached until the end of Kupa River and its inflow to Sava River. 
Table 3

Measured concentrations of all studied sediment samples, including those from Kupica River and their ratios for years 2018 vs. 2003

\begin{tabular}{|c|c|c|c|}
\hline Sample & $\mathrm{Ba}(\mathrm{mg} / \mathrm{kg}) 2003$ & $\mathrm{Ba}(\mathrm{mg} / \mathrm{kg}) 2018$ & Ba 2018/Ba 2003 ratio \\
\hline IŠ * & & 3725 & \\
\hline 51 & 5790 & 1369 & 0.236442 \\
\hline 52 & 75.2 & 317 & 4.215426 \\
\hline 50 ** & 1070 & 782 & 0.730841 \\
\hline 49 & 1060 & 1180 & 1.113208 \\
\hline 5 & 548 & 718 & 1.310219 \\
\hline 2 & 386 & 812 & 2.103627 \\
\hline 4 & 341 & 466 & 1.366569 \\
\hline 9 & 468 & 489 & 1.044872 \\
\hline $13 \mathrm{~K}$ & 262 & 233 & 0.889313 \\
\hline 28 & 199 & 357 & 1.79397 \\
\hline 29 & 74.5 & 212 & 2.845638 \\
\hline 36 & 122 & 332 & 2.721311 \\
\hline 38 & 78.4 & 373 & 4.757653 \\
\hline 45 & 99.2 & 343 & 3.457661 \\
\hline 41 & 54.4 & 256 & 4.705882 \\
\hline 44 & 65 & 185 & 2.846154 \\
\hline \multicolumn{4}{|c|}{$\begin{array}{l}\text { *Data for the year IŠ exists only for the year } 2018 \text {. This location is located on Kupica River. about } 1.8 \\
\mathrm{~km} \text { upstream sample } 51\end{array}$} \\
\hline \multicolumn{4}{|c|}{$\begin{array}{l}* \star \text { For the year } 2018 \text { data do not exist for location } 50 \text {, but sample ČD is taken instead (its location is } \\
\text { about } 5 \mathrm{~km} \text { upstream). That is due to border problems with Slovenia and sampling place } 50 \text { is not } \\
\text { accessible any more. }\end{array}$} \\
\hline
\end{tabular}

\section{Mathematical modelling}

\section{Elevation versus distance from the spring of Kupa}

In order to describe a decrease of elevation, the graph of elevation above sea level versus distance from the spring is examined (Figure 3). In the first attempt we tried to fit an exponential function of the form: $E$ $=E_{O} \exp (-a x)$ where $\mathrm{E}_{\mathrm{O}}=313(\mathrm{~m})$ is the elevation at the spring, $a$ is a free parameter to be determined and $x$ is the distance from the spring in $(\mathrm{km})$. However, the best fit shows the function to have 
insufficiently steep slope close to the spring and insufficiently gentle slope further from the source. This indicates that one should not take the distance as an independent variable but a function of $x$ which grows slower.

Consequently, a law of the type:

$E=E_{o} \exp (-a \sqrt{ } x)(1)$

gives the best fit for $a=0.0767 \pm 0.0015$ (with the RMSE $=11.15$ on $30 \mathrm{df}$ ). The fit to data is shown in Figure 5.

Further comparison of the function to the data in Figure 5 reveals that this law is completely satisfactory until $130 \mathrm{~km}$ when a sudden decrease in elevation occurs. Subsequently, elevation decrease of river Kupa has more gentle slope as it is laid on the Pannonian flatland.

\section{River slope}

From the data used to obtain the Figure 5 one can compute the slope along the river (Figure 6) as the slope is the derivative of water elevation profile.

From Figure 6 it follows that the negative slope starts as over six times greater in absolute value close to the Kupa source than in the region where the river meets the Pannonian Plain.

\section{Barium in sediments}

The concentration of Ba in Kupa River measured in 2003 y. may be fitted by an exponential law:

$B a=B a_{0} \exp (-b x) .(2)$

In the exponential function $B a_{0}=1060(\mathrm{ppm})$ is the concentration value at the entrance of Kupica to the river Kupa, and $x$ is the distance from the entrance. The best fit is obtained for $b=0.0167 \pm 0.0014$ (with RMSE $=83$ on $12 \mathrm{df})$. Let us also note that the law behind the exponential function is: $d(B a) / d x=-b B a$ with the initial condition equal to $\mathrm{Ba}_{0}$.

In order to explain how did the Ba concentration arrive to the distribution shown in Figure 7 during $70 \mathrm{y}$ since the barite mine in Homer started operating and Ba rich particles from the mine waste penetrated the vulnerable karstic underground and through it reached the Kupica River source, a sediment transport model is considered.

The transport model for the concentration of $\mathrm{Ba}(\mathrm{C})$ in Kupa is given by:

$\partial \mathrm{Ba} / \partial \mathrm{t}=+\mathrm{D} \partial^{2} \mathrm{Ba} / \partial \mathrm{x}^{2}-\mathrm{v} \partial \mathrm{Ba} / \partial \mathrm{x}(3)$

with the boundary condition $\left.\mathrm{Ba}\right|_{\mathrm{x}=0}=\mathrm{Ba}_{0}$ and the initial condition $\left.\mathrm{Ba}\right|_{\mathrm{t}=0}=0$, for every $\mathrm{x}>0$. 
The first term in (3) accounts for diffusion of particles while the second term accounts for advection downstream from the entrance of Kupica into Kupa. Since we have no data from which to determine the diffusion coefficient and furthermore, since the turbulent diffusion coefficient is from $10^{-7}$ to $10^{-5} \mathrm{~cm}^{2} / \mathrm{s}$ (Wörman 1998), this term may be safely neglected in considered longitudinal transport.

What remains is the advection of sediment downstream. There are at least two processes of importance for movement of sediment downstream. The first is that during higher precipitation, the horizontal velocity of water increases, increasing vertical turbulent water movement and entrainment of sediment into the water column. This increases advection of sediment downstream. The second process is deposition of sediment at places further downstream where the slope and velocity of water are smaller.

The advection model is discretized with a step $\Delta \mathrm{x}=1(\mathrm{~km})$ and run for $70 \mathrm{y}$ with a $\Delta \mathrm{t}=1(\mathrm{y})$ given the fact that once in a year we have an exceptionally high river flow due to the snow melt, and a constant boundary concentration $B a_{0}=1060(\mathrm{ppm})$ at the entrance of Kupica into Kupa where $\mathrm{x}=0$. The initial condition is set to $\mathrm{Ba}=0$ for all $\mathrm{x}>0$. Since no velocity of sediment was available, we used the discrete law which states:

$B a(j, i)=B a(j, i-1)+c B a(j-1, i)-d B a(j, i-1) ; j=1, \ldots, 300, i=1, \ldots, 70 ;(4)$

and adjusted $c=0.75$ and $d=0.76$ for the best fit to data measured in $2003 \mathrm{y}$.

The resulting simulation is shown in Figure 8.

From Figure 8 it is seen that the initial concentration at $t=0$ is located only at the entrance of Kupica into Kupa. Through the 70 years it has gradually moved downstream. Finally, it appears as an exponential distribution of $\mathrm{Ba}$ in sediments reaching over 200 km downstream Kupa River.

It is important to point out that an attempt to use $a=b$ failed to fit the data from $2003 \mathrm{y}$ for any value of $a$ since it produced too steep a slope of Ba concentration. This strengthens the discovery that indeed at any distance downstream from the entrance of Kupica into Kupa, $75 \%$ of the sediment containing Ba is added per km peryear from upstream and $76 \%$ of the sediment found at the location is transported downstream.

\section{Verification using the data of $2018 \mathrm{y}$.}

Using the same transport parameters $a$ and $b$, the model was run until $2018 \mathrm{y}$. The comparison until 130 km downstream the entrance of Kupica into Kupa reveals a good agreement to the data (Figure 9).

For the explanation of the "bump" in the distribution occurring from 2003 to $2018 \mathrm{y}$ downstream from $130 \mathrm{~km}$ shown in Figure 9, one has to invoke at most two new factors to the model. The first is that downstream beyond $130 \mathrm{~km}$, the elevation slope is significantly smaller so the deposition potential is greater. The second factor is that in this time interval, one or more violent precipitation events may have happened which caused entrainment of heavier sediment into the water column at the stretch of the river 
prior to $130 \mathrm{~km}$ (where the water velocity is greater) and deposition downstream beyond $130 \mathrm{~km}$ where the river water flows practically along a flat plain causing significantly slower movement of water and hence greater deposition potential of sediment from the water column.

In the model only the first factor has been simulated as a gradual slightly greater deposition then loss past $130 \mathrm{~km}$ during $15 \mathrm{y}$, i.e. from 2003 to $2018 \mathrm{y}$.

The Figure 9 shows the result of two pieces of simulation. The last exponential function (the envelope) until $130 \mathrm{~km}$ represents the result that the distribution would have had if the same simulation, which is shown on Figure 8 , is continued to 2018 y i.e. 15 year longer.

The concentration "bump" is obtained by simulation of the part beyond $130 \mathrm{~km}$ with $c=0.75$ and $b=$ 0.74. Another words, with the same import from upstream as in the period until $2003 \mathrm{y}$ but with only slightly greater deposition, or equivalently, with smaller release of sediment downstream from 2003 until $2018 \mathrm{y}$.

However, as stated above, the same shape of the distribution beyond $130 \mathrm{~km}$ downstream the source may be explained by one or more violent precipitation events which have moved sediment from the upper part of Kupa over the sudden change of elevation slope into the flat land. Indeed, the examination of historical data on violent precipitation events in the last $100 \mathrm{y}$. reveals the highest flood during $2015 \mathrm{y}$ and the second highest flood during $2014 \mathrm{y}$. The floods in 2014 and 2015 alone could have moved the sediment downstream in agreement with the data in Figure 4.

Finally, high concentration of $\mathrm{Ba}$ in sediments measured in Kupa $200 \mathrm{~m}$ upstream from the entrance of Kupica (station 52) during 2003 and 2018 may be explained by diffusion of sediments upstream. As for the explanation of the two somewhat higher values above the background level of Ba closer to the source of Kupa, the likely mechanism may be that during an event of intensive precipitation in the Kupa watershed, $\mathrm{Ba}$ is transported into Kupa through the porous karstic bedrock from the mine deposit uphill. The same mechanism was found to be responsible for occurrence of $\mathrm{Pb}$ in the beach sediments which were transported through porous karstic rock from uphill lead processing workshop into the Punat Bay of the Adriatic Sea (Legović et al. 1990).

From measurement and modelling results it may be predicted what will happen to Ba concentration in Kupa during the next $20 \mathrm{y}$.

First, the Ba source will not cease any time soon. It may decrease further but it will not completely vanish in the near future. Given the fact that barite mine was closed in 1990, we see Ba concentration upstream of Kupica entrance into Kupa is still increasing in 2018, 38 years later. This means that Ba entrance into Kupa through a porous karstic rock is still higher than erosion downstream. Likewise, Ba concentration downstream Kupica entrance into Kupa is still increasing testifying again that entrance is higher than erosion downstream. However, there is a sign that this process started decreasing as Ba concentration in sediment at the location 51 (Kupica River just before its inflow into Kupa River) was in the year 2018 
about 4 times lower than in 2003 (see Table 3). Also, at the first downstream location from the Kupica confluence (50) Ba concentration in sediment was almost 30\% lower in the year 2018 than it was in 2003 (see Table 3). This is obviously a sign that parts of karstic underground leading towards Kupica River source are gradually being washed out. If this process persists, in the future we might expect further decreasing of Ba concentrations in the upper course of the Kupa River, while in the lower course this will not happen so soon. Finally, a peak of Ba concentration downstream from $130 \mathrm{~km}$ has a potential to increase further and in part be transported further downstream. Hence, by the end of next 20 y we do not expect that Ba concentration will decrease in the lower part of the Kupa River, especially downstream of Ozalj powerplant. To the contrary, we expect an increase throughout Kupa, except on part of its upper flow just downstream of Kupica River inflow.

\section{Conclusions}

Results obtained within the current paper led to the following conclusions:

- After barite mine in Homer ceased operation in 1990, Ba is still entering Kupica and Kupa rivers, as karstic underground still contains large amounts of barite waste. Our results have shown that between the years 2003 and 2018 Ba concentrations in sediments are still increasing consequently along the whole river length, with the exception of sampling point in Kupica River before its inflow to Kupa and first sampling point in Kupa River downstream the confluence with Kupica.

- The significant decrease of Ba content in Kupica River sediment and first downstream sediment sample in Kupa River are signs that a reversal started due to the process in which parts of karstic underground leading towards Kupica River source are gradually being washed out of barite waste. Now in this part of river course erosion exceeded deposition processes.

- An important finding is that between the years 2003 and 2018 Ba concentrations in sediments significantly increased at the sampling point upstream the Kupica River inflow. This could mean that present Ba-waste in the karstic underground found another way. Except flowing to Kupica River source, now part of it enters Kupa directly at the stretch of river upstream Kupica inflow. But, obviously these quantities entering Kupa are now not so large as before. This is indicated by the fact that on the first downstream location Ba concentrations started to increase i.e. that erosion now exceeds deposition.

- About $150 \mathrm{~km}$ downstream from Kupica River inflow into Kupa there is a peak of Ba concentrations. We assume that it was formed under one or two flood episodes, which happened between 2003 and 2018, namely 2014 and 2015. During such events of extremely high water discharge, sediment may have eroded from the upstream locations, brought downstream and finally deposited in the lower course of the river.

- From measurement and modelling results it may be predicted what will happen to Ba concentration in Kupa River sediments during the next 20 years. We predict that Ba source will not cease completely during that period. Although, in most part of the river length, except the uppermost part downstream Kupica River inflow, Ba deposition will still be smaller than erosion. However, in the 
lower-most part of Kupa, concentrations will be increasing since there deposition is greater than erosion.

- Further research of this interesting phenomenon is advised. Especially, it will be important to perform new sampling at the same locations in the future, e.g. in 5, 10 or 15 years after the last sampling campaign from the year 2018. First, this would enable computing an estimate of the rate of decrease of Ba inflow into Kupa. Second, it would enable answering te question of whether Ba will eventually enter Sava river or it will be accumulated, buried and compactified further into the present peak section of the Kupa.

\section{Declarations}

Funding: Research was partially funded by Ministry of Science and Education of Republic of Croatia (Grant No: 0411FI18).

Conflicts of interest/Competing interests: We state that there is no conflict of interest or competing interests.

Availability of data and material: All our data and materials used for the current research are transparent and available.

Code availability: For part of modelling software R version 3.5.1, 2018 was used.

\section{Author contribution:}

Stanislav Frančišković-Bilinski designed the research, led the field work, sampling and sample preparation, and led manuscript writing;

Krešimir Maldini performed laboratory analysis (dissolving sediment samples and performing ICP-MS analysis);

Halka Bilinski participated in the field work, sampling and sample preparation, advised about chemical part of the research and helped with manuscript design.

Tarzan Legović performed modelling, wrote modelling chapters and helped with manuscript design.

Ethics approval: We approve that our manuscript is performed within all ethical standards and requirements.

Consent to participate: All authors gave their consent to participate in the current research.

Consent for publication: In the case of manuscript acceptance we give our full consent for its publication according to Journal and Publisher conditions. 
Field trips in the Kupa River basin in the year 2018 were funded by Ministry of Science and Education of Republic of Croatia (Grant No: 0411FI18), which is also thanked for financial support. We thank Simana Milović from Hrvatske vode (Croatian water authorities) for help with sample preparation.

\section{References}

1. Ancey C, Bohorquez P, Bardou E (2014) Sediment transport in mountain rivers. ERCOFTAC Bull 100:37-52

2. Biondić B, Biondić R, Kapelj S (2006) Karst groundwater protection in the Kupa River catchment area and sustainable development. Environ Geol 49:828-839

3. Ciszewski D, Grygar TM (2016) A Review of flood-related storage and remobilization of heavy metal pollutants in river systems. Wat Air Soil Poll 227:239. https://doi.org/10.1007/s11270-016-2934-8

4. Einstein H (1942) Formulas for the transportation of bed load. Trans Am Soc Civil Eng 107:561-597

5. Frančišković-Bilinski S (2005) Geochemistry of stream sediments in Kupa River drainage basin, Dissertation, University of Zagreb, Croatia

6. Frančišković-Bilinski S (2006) Barium anomaly in Kupa River drainage basin. J Geochem Explor 88:106-109

7. Frančišković-Bilinski S (2007) An assessment of multielemental composition in stream sediments of Kupa River drainage basin, Croatia for evaluating sediment quality guidelines. Fresenius Environ Bull 16:561-575

8. Frančišković-Bilinski S, Bhattacharya AK, Bilinski H, Bhattacharya BD, Mitra A, Sarkar SK (2012) Fluvial geomorphology of the Kupa River drainage basin, Croatia: A perspective of its application in river management and pollution studies. Z für Geomorph 56:93-119

9. Frančišković-Bilinski S, Bilinski H, Scholger R, Tomašić N, Maldini K (2014) Magnetic spherules in sediments of the karstic Dobra River (Croatia). J Soils Sediments 14:600-614. https://doi.org/10.1007/s11368-013-0808-x

10. Förstner U (2004) Sediment dynamics and pollutant mobility in rivers: An interdisciplinary approach. Lakes Reservoirs: Res Managem 9:25-40

11. Lauer JW, Parker G (2008) Modeling framework for sediment deposition, storage, and evacuation in the floodplain of a meandering river: Theory. Wat Resour Res 44:W04425. https://doi.org/10.1029/2006WR005528

12. Legović T, Limić $N$, Valković V (1990) Estimation of diffuse inputs to a coastal sea: solution to an inverse modelling problem. Estuar Coast Shelf Sci 30:619-634

13. Mujić M (2016) Protection and rescue from floods in Karlovac city. University of Applied Sciences Karlovac, (in Croatian). https://repozitorij.vuka.hr/islandora/object/vuka\%3A442/datastream/PDF/view

14. Nazir MHM, Awang S, Shaaban AJ, Yahaya NKEM, Jusoh AM, Arumugam MARMA, Ghani AA (2016) Sediment transport dynamic in a meandering fluvial system: Case study of Chini River. Soft Soil 
Engineering International Conference 2015 (SEIC2015), IOP Conf. Series: Mater Sci Eng 136:012072. https://doi.org/10.1088/1757-899X/136/1/012072

15. Park SW, Ahn J (2019) Experimental and numerical investigations of primary flow patterns and mixing in laboratory meandering channel. Smart Water 4:4. https://doi.org/10.1186/s40713-0190016-y

16. Wörman A (1998) Analytical solution and timescale for transport of reacting solutes in rivers and streams. Wat Resour Res 34:2703-2716

17. Yilmaz $L$ (2008) Experimental study of sediment transport in meandering channels. Wat Res Manag 22:259-275

\section{Figures}




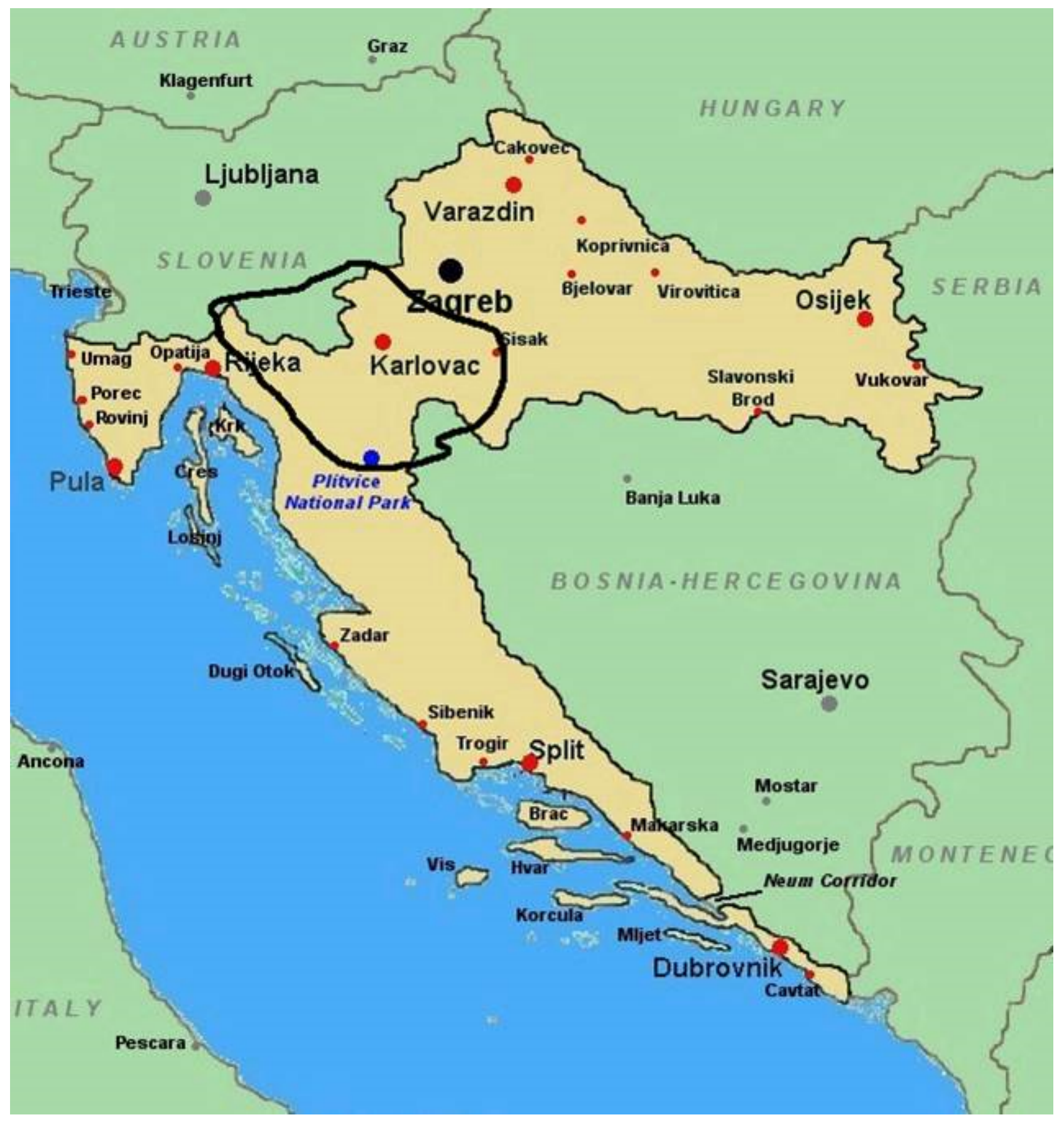

Figure 1

Position of Kupa River drainage basin within Croatia and neighbouring countries. 


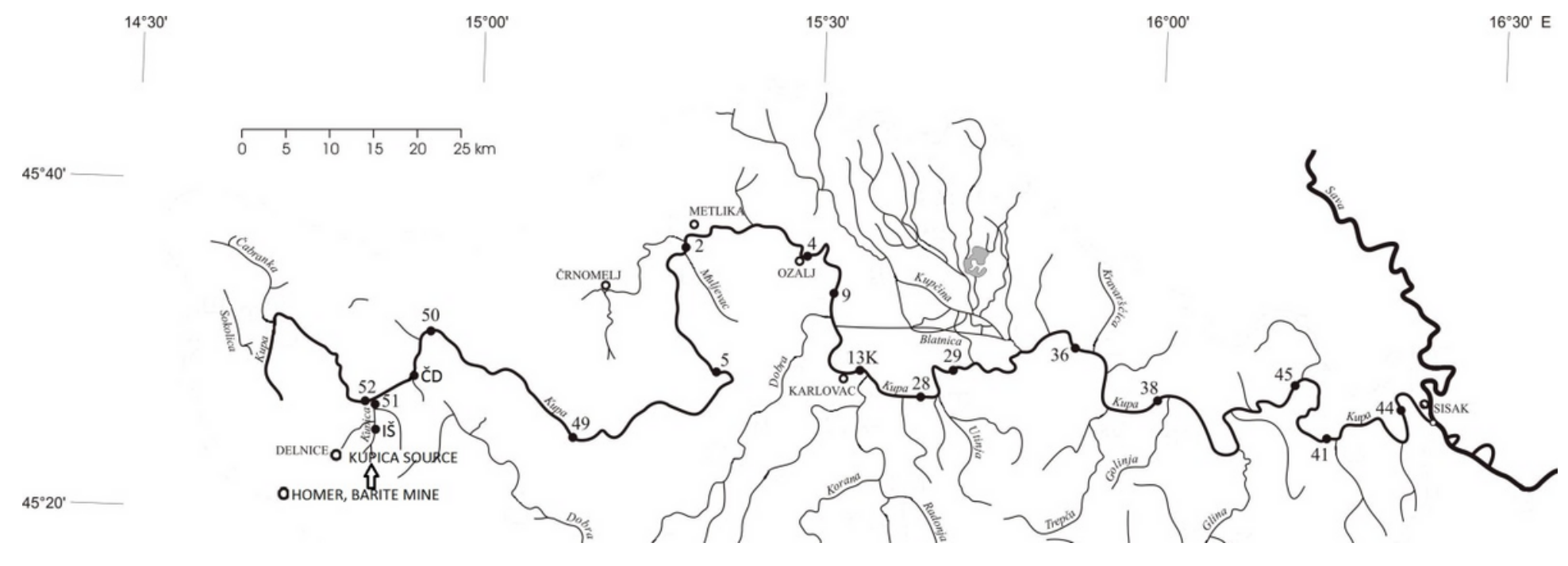

Figure 2

Position of barite mine in Homer and of sampling stations along the Kupa River.

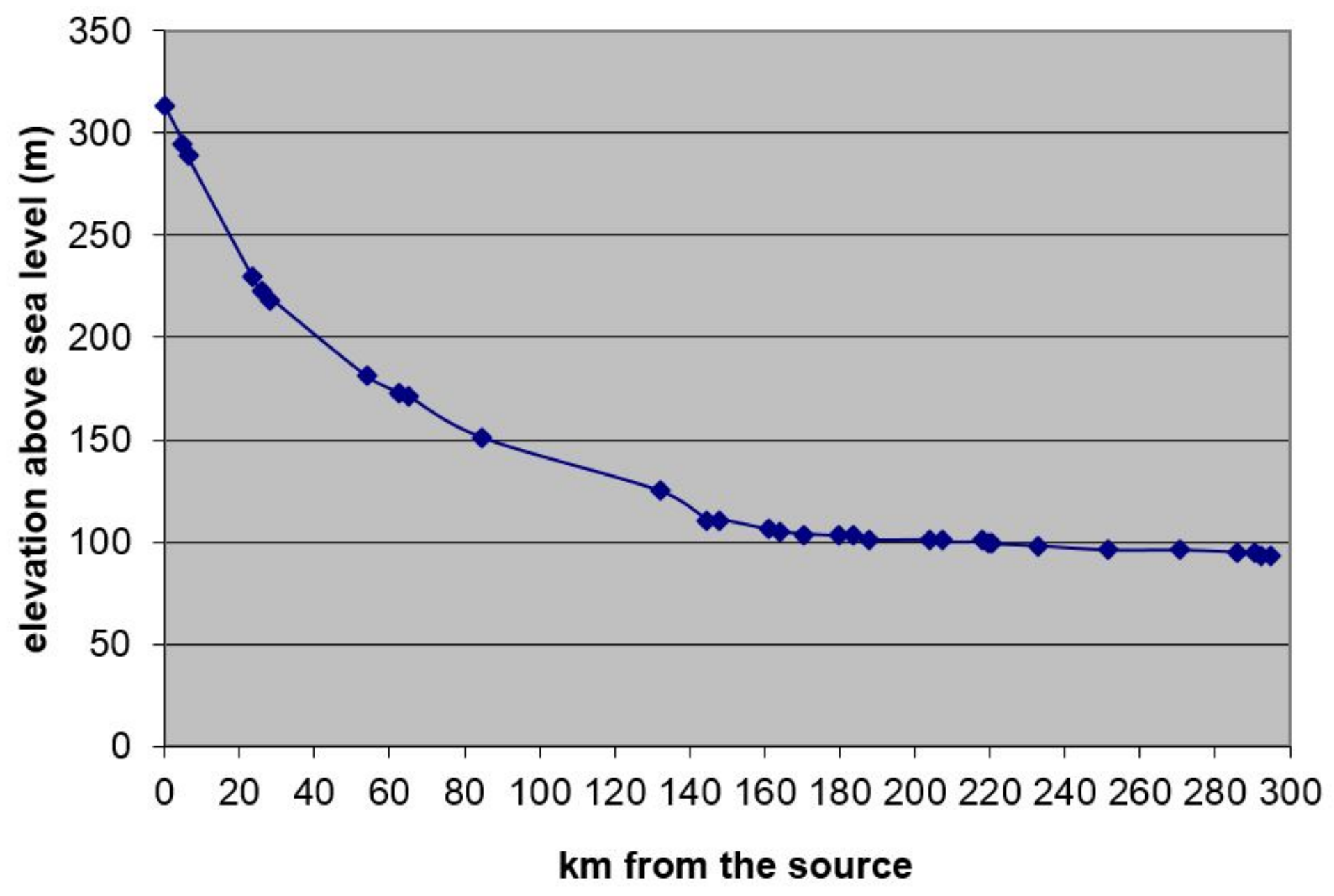

Figure 3

Kupa river: Longitudinal water elevation from its source until inflow into the Sava River. 


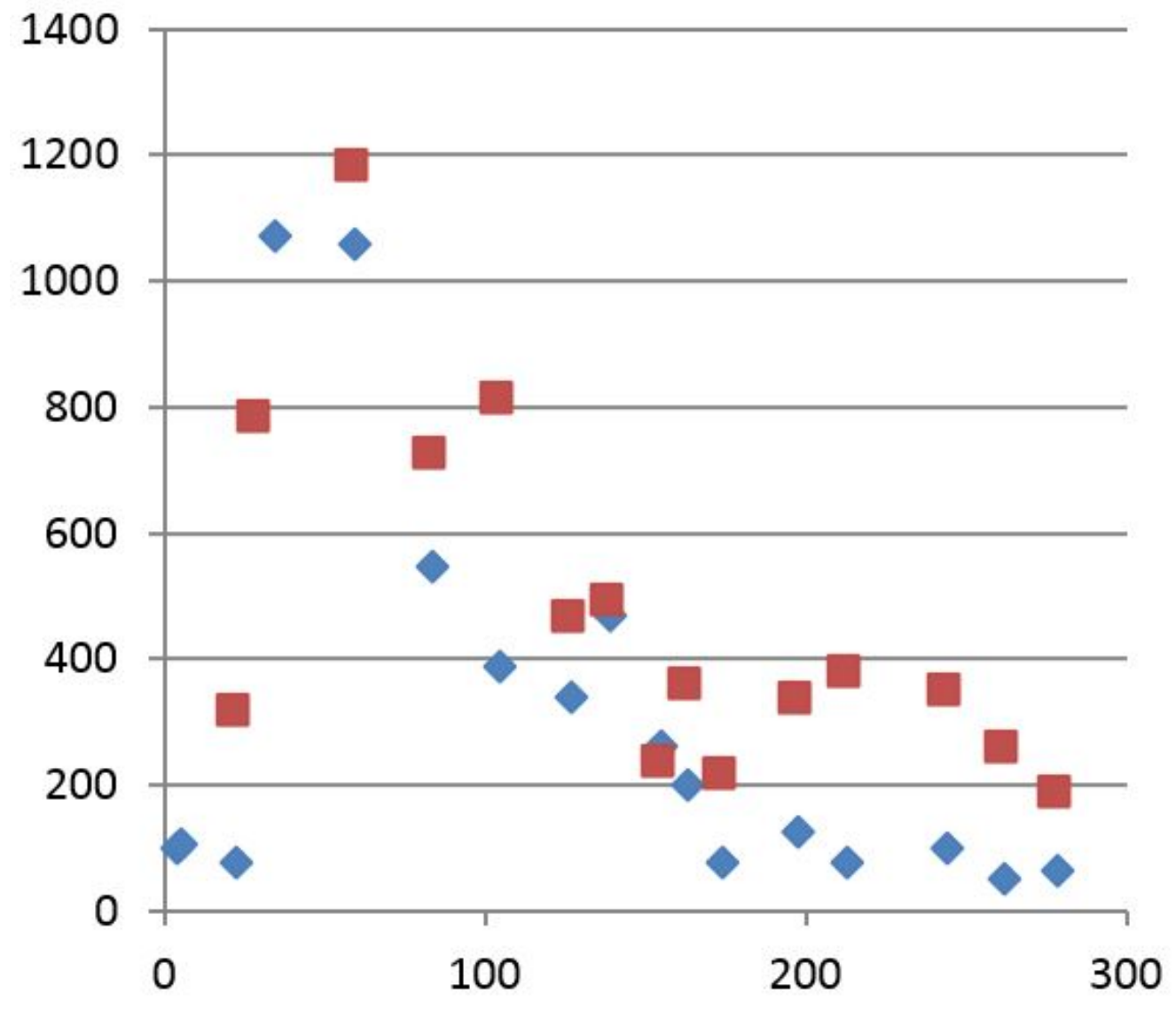

Kupa Ba (ppm) 2003 Kupa Ba (ppm) 2018

\section{Figure 4}

Ba concentrations in sediments of the whole length of Kupa River in both studied years (2003 and 2018).
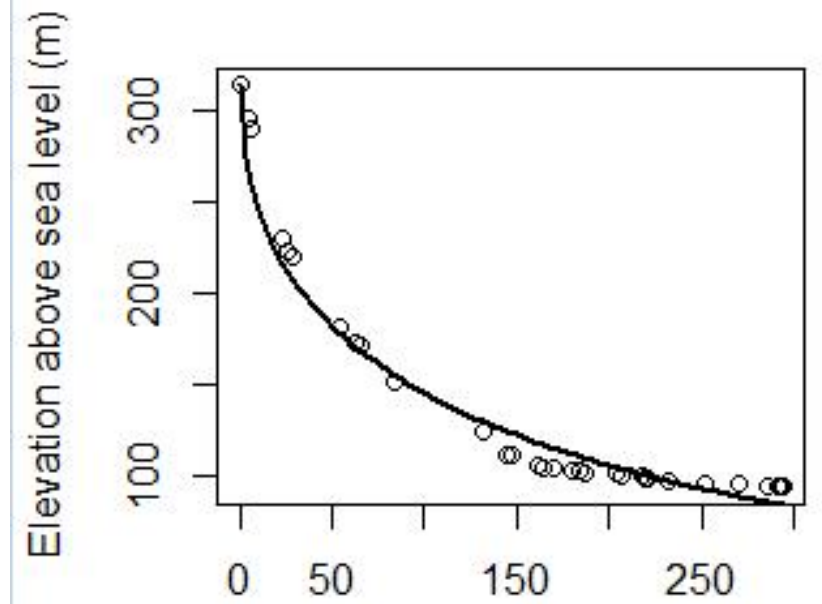

Distance from the source $(\mathrm{km})$

\section{Figure 5}

The elevation above the sea level, $E$, in $(m)$, versus the distance, $x$ in $(\mathrm{km})$ from the spring of Kupa. The law of the type $E=E 0 \exp (-a \sqrt{ } x)$ is fitted to data, given E0 $=313(\mathrm{~m})$ elevation at the spring. The best fit is obtained for $\mathrm{a}=0.0767$. 


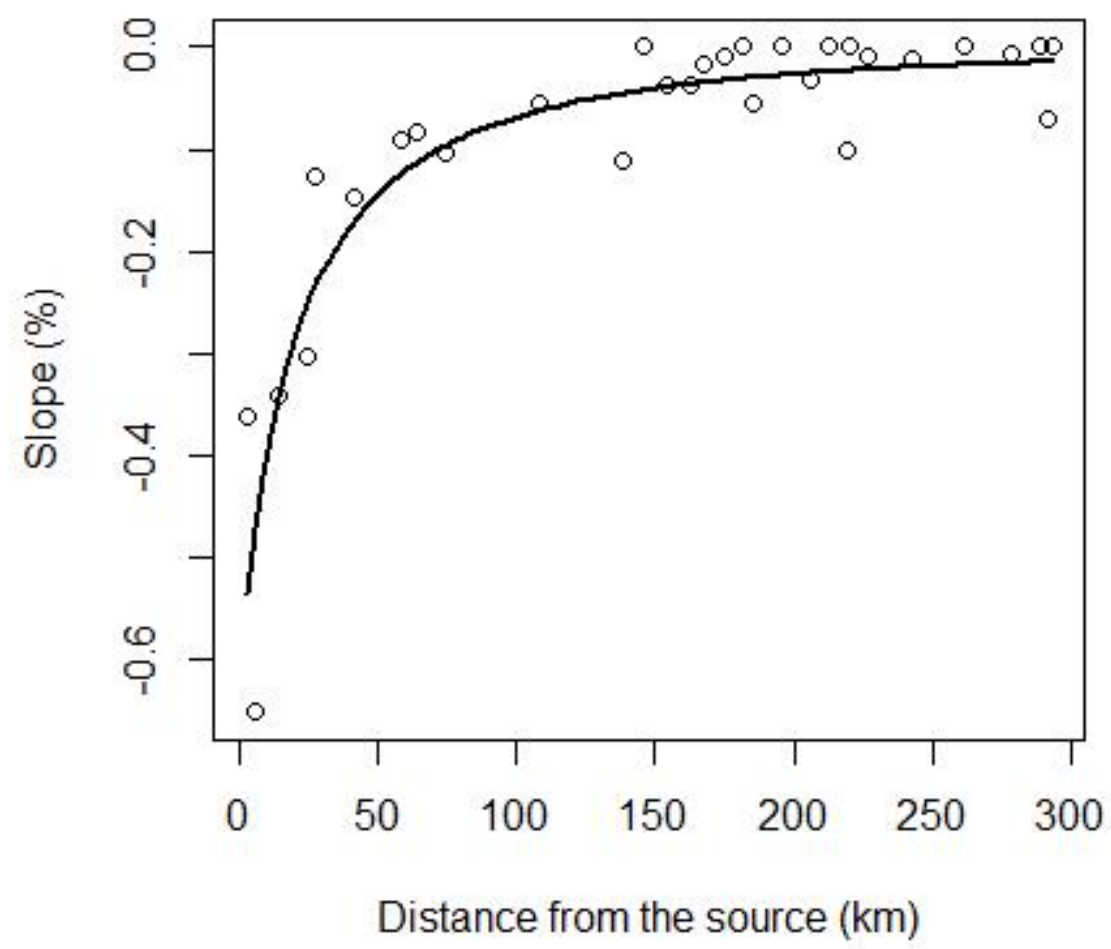

Figure 6

The slope of the Kupa River. The slope is calculated from the data in Figure 5.

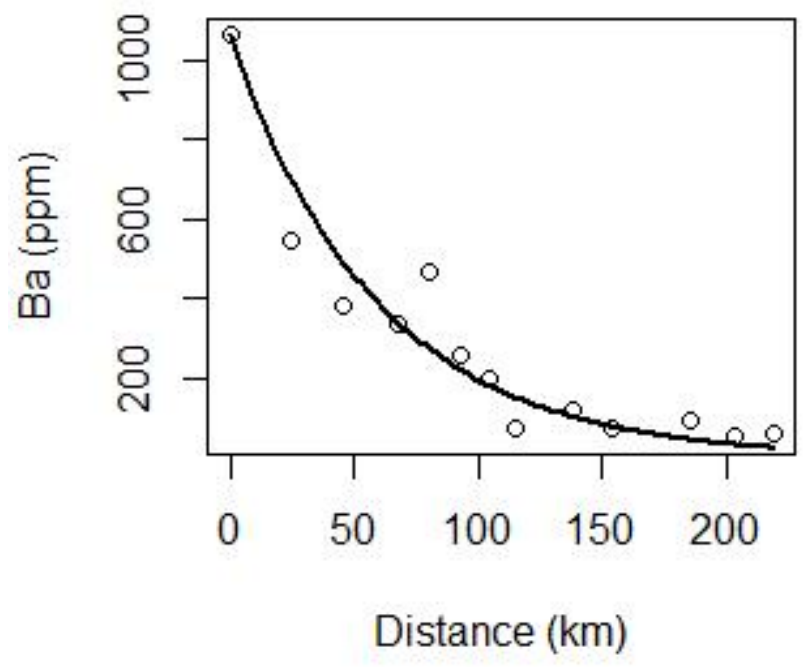

Figure 7

Barium in sediments of the river Kupa measured during $2003 \mathrm{y}$. The best fit to data is obtained by an exponential function $\mathrm{Ba}=\mathrm{Ba} 0 \exp (-\mathrm{b} \mathrm{x})$, where $\mathrm{Ba} 0=1060(\mathrm{ppm})$ is the concentration value at the entrance of Kupica into Kupa, $x$ is the downstream distance from the entrance, and $b=0.0167$. 


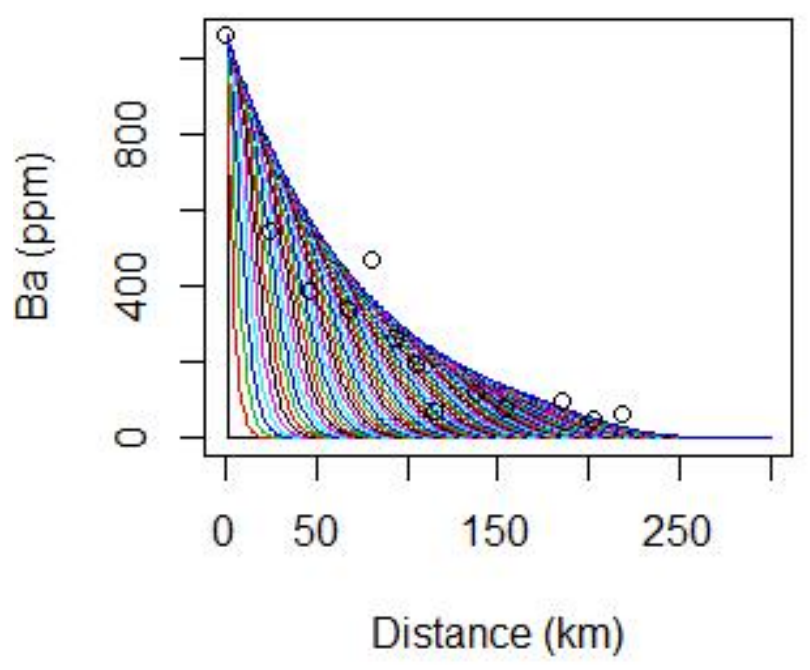

\section{Figure 8}

Dynamics of Ba distribution in the sediment of the Kupa River. The simulation starts at $t=1$ and ends up at $t=70 \mathrm{y}$ when the concentration has reached values measured in $2003 \mathrm{y}$. (denoted by circles).

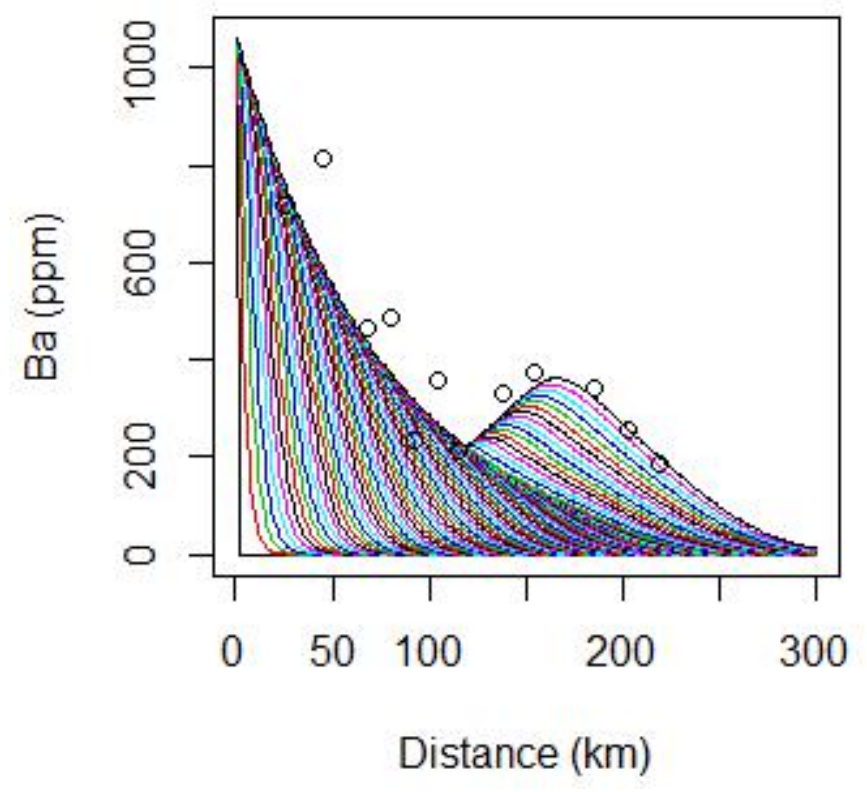

Figure 9

The comparison of the distribution of Ba in sediments of Kupa River measured during $2018 \mathrm{y}$. with a simulation. 